LETTER TO THE EDITOR

\title{
What is the distance between saying and doing?
}

\author{
Marcelo Carneiro ${ }^{1}$, Manuela Suzana Persch ${ }^{1}$, Jenifer Grotto Souza ${ }^{1}$, \\ Eliane Carlosso Krummenauer'2, Janete Aparecida Alves Machado² \\ ${ }^{1}$ Santa Cruz do Sul University, Brazil \\ ${ }^{2}$ Santa Cruz Hospital, Brazil
}

doi: 10.3396/ijic.v8i2.020.12

\author{
Key words \\ CROSS INFECTION - prevention and control; HANDWASHING; INSERVICE TRAINING; HEALTH \\ PERSONNEL - education
}

Hand hygiene $(\mathrm{HH})$ is a simple action of great importance in the prevention of nosocomial infections. Studies show that the hands of healthcare professionals are a reservoir of pathogens with deleterious effects for both patients and workers. Despite evidence demonstrating the magnitude in the chain of transmission of nosocomial infections and the effects of $\mathrm{HH}$ procedures to reduce these indicators, many professionals have a passive attitude towards the problem, which leads to discussions on the difference between saying and doing it. ${ }^{1}$

Regardless of the health service structure, of the guidelines provided and available resources, the problem with poor adherence to $\mathrm{HH}$ habit is evident in most health services. Although there is a unanimous perception amongst healthcare workers on its importance, studies have shown that up to $70 \%$ of professionals perceive education as the most important strategy in implementing these practices. ${ }^{2}$ We also observed the relevance regarding microbial resistance through the associated use with microbial control in reducing rates of carbapenem-resistant Pseudomonas aeruginosa. $^{3}$

The HH habit is a topic discussed since childhood that is no strictly followed by a high percentage of the population, including health professionals, which makes us wonder: What happens between the recognition of a practice as essential and the capacity to make it into a habit? What leads properly trained, encouraged and, in theory, aware individuals not to

\section{Corresponding author}

Prof. Marcelo Carneiro, MD, MSc

Faculty of Medicine, Santa Cruz do Sul University, Santa Cruz do Sul - Rio Grande do Sul Brazil

Email: carneiromarcelo@yahoo.com.br 
optimize this simple habit? What is the reason for the increase in $\mathrm{HH}$ during peaks of infectious disease outbreaks, as observed during the H1N1 pandemic in 2009 and the subsequent lack of maintenance? ${ }^{4}$ How can training programs in healthcare services solve this problem?

We draw on the possibility of a new focus on health education strategies that have the capacity to transform rules into habits, which will encourage a different view, rather than an imposition, to infection control professionals, to promote it as a positive attitude, recognizing it as a symbol of self-care and responsibility with the assisted patients.

\section{References}

1. Mundy LM. Contamination, acquisition, and transmission of pathogens: implications for research and practice of infection control. Infect Control Hosp Epidemiol 2008; 29: 590-592. http://dx.doi.org/10.1086/589558

2. Birks $M$, Coyle $M$, Porter J, Mills J. Perceptions of hand hygiene amongst health care workers in Sibu, Malaysia. Internat Journal of infection Control 2011; 8: 10-13.

3. Santos RP, Jacoby T, Pires Machado D, et al. Hand hygiene, and not ertapenen use, contribute to reduction of carbapenem-resistant Pseudomonas aeruginosa. Infection control and hospital epidemiology 2011; 32: 584-590. http:// dx.doi.org/10.1086/660100

4. Santos RP, Konkewicz LR, Nagel F, et al. The 2009 H1N1 Influenza A Pandemic and Hand Hygiene Practices in a Hospital in the South of Brazil. Infect Control Hosp Epidemiol 2010; 31: 1313-1315. http://dx.doi.org/10.1086/657582 